Sonja Georgi / Kathleen Loock

\title{
Of Body Snatchers and Cyberpunks: Teaching American Science Fiction Film
}

In 2006, the German Association for American Studies (DGfA) held its annual conference at the University of Göttingen. The conference topic, "American Studies as Media Studies," paid tribute to the different turns that have (re)shaped the field of literary and cultural studies after the linguistic, historical, and cultural turns of the 1970s and 1980s. ${ }^{1}$ Throughout the past two decades, new theoretical and methodological approaches have emerged that take into account different contemporary and historical mediations of (trans)national or cultural representations and have led to an expansion of American Studies as a discipline. In accordance with the overall topic, the conference program challenged the traditional hegemony of the printed word by including papers that focused on visual, audio-visual, and audio formats as well as on new electronic media. In other words, the conference "American Studies as Media Studies" came to terms with the fact that we live

1 For a discussion of recent theoretical turns in literary and cultural studies see BachmannMedick. 
in an increasingly audio/visual environment that is largely influenced by different kinds of new media. ${ }^{2}$

Our world is no longer governed by the logocentrism that has formed the basis of Western thinking: The written word has been losing its monopoly in our everyday lives because other semiotic channels - taking the forms of images, sounds, and spectacles - increasingly attract our attention (Seidl 2). Media and technology - the sight and sound of radio, television, film, music, photos, paintings, the Internet, computer games, but also print media such as magazines, newspapers, and comic books - have become an inescapable part of our existence (Kellner 1-2). Along these lines, Eckart Voigts-Virchow rightly states that "[w]e live in a thoroughly 'mediatized' world, a social and cultural environment which is permeated by the media, and more specifically electronic media" (5). In addition, Frank Kelleter and Daniel Stein have drawn attention to the major role the United States play in our media culture:

If we find it increasingly difficult to distinguish between what is universal and what is local - even between what is virtual and what is material - this has much to do with the presence of the media in our lives. And one cannot help but add: it has to do with the presence, both virtual and material, of the United States of America in our lives. (ix)

American Studies as a discipline provides tools to read not only contemporary but also historical non-verbal texts in order to (re)consider their cultural work both inside and outside the United States. The new focus on media other than the printed text is reflected in the American Studies programs at German universities. Apart from lectures and courses that deal with works from the traditional literary canon - which has already been expanded to include American literatures by women and minority writers - American Studies curricula now also offer courses on popular music, comic books and graphic novels, television series, and, of course, on film. ${ }^{3}$

American popular culture and mass media, it seems, fulfill at least one of the essential criteria Peter Freese lists for the selection of classroom texts or topics: "intrinsic motivational power" (193). Films in particular are an attractive and - to a certain degree - familiar medium for students, both at school and university (Surkamp, "Teaching Films" 3). But this is not the only reason for teaching films. What is more important - especially on the level of academic American Studies

2 The conference program is available online; see American Studies as Media Studies: 53. Jahrestagung der Deutschen Gesellschaft für Amerikastudien. See also the conference volume American Studies as Media Studies, edited by Frank Kelleter and Daniel Stein.

3 Voigts-Virchow somewhat critically assesses the number and contents of media-related courses in English and American Literary and Cultural Studies at German, Austrian, and Swiss universities from 1999 to 2004 (9-13). He laments "the sad fact that media studies have not been fully absorbed" into university curricula, even though, recent introductions to literary studies "have featured chapters on the media or at least on film" (11). 
directed at future teachers - is the necessity for critical media literacy. Douglas Kellner believes that "McLuhan to the contrary, today's media-saturated younger generations are not naturally media-critical or truly media-literate" (335). Indeed, many students of American Studies continue to understand and experience films along the lines of their everyday (and hence often unreflected) contact with Hollywood cinema or U.S. American television programs. American Studies curricula must therefore address precisely this unreflectedness and teach how "to read moving images as well as to deal competently and critically with them" (Surkamp, "Cultural Approach" 15-16).

In his book Media Culture: Cultural Studies, Identity and Politics between the Modern and the Postmodern, Kellner observes that rejecting or neglecting mass culture, as the Frankfurt School did, might be inappropriate today, because "media culture is here to stay and, if anything, its products are becoming increasingly popular and powerful" (335). He is further convinced that a "mindless celebration of media culture, without cultivating methods to promote critical media literacy, is equally pernicious" (335) and thus comes to the following conclusion:

$[1] \mathrm{t}$ is important to pursue a project of developing a critical media pedagogy and to teach ourselves and others how to critically decode media messages and to trace their complex range of effects. It is important to be able to perceive the various ideological voices and codes in the artefacts of our common culture and to distinguish between hegemonic ideologies and those images, discourses, and texts that subvert the dominant ideologies.

Similarly, Carola Surkamp's research on the teaching methodology of film stresses that the knowledge about film is essential for the orientation in a media society, "because filmic devices have a deep impact on our viewing habits, the formation of our opinions ... and the perception we have of other cultures" ("Cultural Approach" 28).

In this larger context, we conceived the idea of teaching parallel undergraduate courses on American science fiction film at the University of Göttingen and the University of Siegen that were to end with a joint conference. In the summer term of 2009, students from Göttingen and Siegen watched, analyzed, and discussed six science fiction films from the 1950s to the present; they gave papers in class and at the joint conference, wrote term papers, and continuously revised their work. One of the primary goals of this joint format was to provide students with an alternative learning experience that not only increases their motivation but also accentuates their academic research and performance skills. The final result of the undertaking is the present volume of student essays.

In the following, we will outline the theoretical, methodological, and didactic considerations that informed the planning and teaching processes of these two courses and the conference - considerations that should also give more general 
insights into new and/or different ways of teaching at university level. More precisely, in Part II, we will discuss the question of why American science fiction film provides an appropriate genre to teach critical media literacy and address a number of important issues both from filmic and cultural studies perspectives. We further elaborate on the choice of six specific films released in the decades from the 1950s to the 2000s. In Part III of this essay, we will then address the course format, organization, and content as well as the didactic approaches and methodology. We will deal with the question of how to teach film in general and science fiction film in particular in an American Studies context. Finally, Part IV briefly presents the structure and content of this volume.

\section{II}

Science fiction film as an essential element of American popular culture provides a valuable source for teaching media literacy in the American Studies classroom. The recent productions of Hollywood blockbusters and film remakes such as $W$ ar of the Worlds (Spielberg, 2005), I am Legend (Lawrence, 2007), and The Day the Earth Stood Still (Derrickson, 2008) attest to the continuing relevance of science fiction in contemporary mainstream culture. At the same time, science fiction allows students to investigate reigning attitudes toward social, political, cultural, and/or ecological developments in U.S. society by "embedding films in their historical and socio-cultural context as well as in the contemporary discourses in which they partake" (Surkamp, "Cultural Approach" 28). Since its beginnings, science fiction has served as an intellectual playground where pressing issues (such as scientific and technological progress, population growth, nuclear power, environmental protection, genetic engineering) have been projected onto different times and spaces in order to warn about inherent dangers, offer solutions, or simply speculate about and experiment with the future. In this function, they can provide insights into U.S. American cultural imaginaries. When analyzed as cultural products, science fiction films can also shed light on U.S. American cultural realities and enable a further understanding of particular historical and political contexts.

Most consumers of popular culture are to a certain degree familiar with science fiction and recognize specific generic elements and conventions. Or, as Jay P. Telotte writes, sporadic science fiction viewers and fans alike are able to formulate an amateur definition of science fiction: "Anyone who has watched even a few science fiction films, episodes of a Flash Gordon serial, or several episodes of the Star Trek or Babylon 5 television series, for example, would probably argue that he or she could, with little hesitation, decide if a certain work belongs within the science fiction category" (17). This assumption is based on the idea that science fiction films share what Telotte calls "particular hallmarks, visual icons, that, over the course of many years, have helped constitute a common signature that cultural consensus or historical use has by now assigned to the genre" (17). The "common 
signature," or "language," of science fiction film that Telotte describes in his book Science Fiction Film includes character types, situations, and settings as well as tools and weapons - to name but a few central filmic devices (17).

As a consequence, an undergraduate course on American science fiction film from the 1950s to the present (such as the one we taught at the University of Göttingen and the University of Siegen) can draw on the students' familiarity with U.S. American popular culture as well as on their familiarity with science fiction films and literature - albeit without taking their media or genre skills for granted. The students' prior knowledge of medium and content should only be the starting point for a more theoretical and historically guided approach to science fiction film. ${ }^{4}$

Eric S. Rabkin situates the beginnings of science fiction in the romantic period and defines it as an umbrella term for literature that "both warns against and applauds the advance of science and technology" ("Science Fiction" 19). As a genre, science fiction is both characterized by its "ambivalence toward the institutions of science and technology" and its interest in the encounter with the other, often in the form of new technologies, worlds, and beings (19). According to Rabkin, science fiction in general is concerned with the dangers of science and technology, yet at the same time it also celebrates the unlimited potentials of science and technology (19). Today, the beginning of the genre is often linked to the publication of Mary Shelley's Frankenstein in 1818 because the novel reflects many of the changes from an agricultural to an industrial society based on recent scientific findings. ${ }^{5}$ When discussing the further development of the genre, it is important to differentiate (1) between science fiction literature and film and (2) between European and American seminal science fiction works. With regard to the first point, one could state that thematically, science fiction film and literature share their concern with contemporary scientific and technological developments. Yet, Vivian Sobchack writes, "SF film is less contemplative and analytic and more spectacular and kinetic than its literary counterparts" (“American Science Fiction Film” 263). Concerning the second observation, Rabkin postulates a major difference between European and American science fiction with reference to their attitudes towards the exploration of space and the crossing of ever new frontiers. According to Rabkin, in European science fiction, the (usually male) hero takes the role of the adventurer who upon meeting the alien turns into himself and eventually, in the tradition of the Robinsonade, returns home. The American science fiction hero on

4 The question of what science fiction actually is and which works qualify as science fiction seems to be characteristic for the genre and acclaimed scholars of the field like Darko Suvin, Brian Aldiss, and Robert Scholes and Eric S. Rabkin advocate different approaches to, and definitions, of the genre. In the introductory sessions of the course, students could be shown a selection of definitions of the genre and asked to compare these approaches to science fiction (literature) with their own ideas of what constitutes science fiction.

5 However, Frankenstein is also, or foremost, regarded as a classic work of the romantic period in Britain and of the gothic genre (Maxwell 7). See also Rabkin, Brian Aldiss, and Edward James. 
the other hand, following the tradition of the Western, crosses the frontier with the aim to change and improve the new territory ("American Science Fiction Film: No Final Frontiers"). About the cultural significance of the science fiction genre for American society in the twentieth century Rabkin remarks:

Just as a mushroom cloud and a single footprint on the moon are this era's linked icons of despair and hope, so science fiction in both warning against arrogance and proselytizing for perpetual discovery embraces our deep ambivalence toward the institutions of science and technology, their products, and their effects on humanity. ("Science Fiction" 19)

Following this observation, we argue that American science fiction has specific themes that derive from, and only make sense within, specific American historical, cultural, and social contexts. The Industrial Revolution of the late eighteenth and nineteenth centuries, for example, resonates in American science fiction of the twentieth century in discourses on a growing U.S.-based global capitalist system, while the exploration of new territories takes the exploration of the New World as its model. In this context, Brian Aldiss notes that even though " $\mathrm{t}]$ he origins and inspirations for science fiction lie outside of the United States ... [s]cience fiction ... is now largely - in emphasis and in fact - an American art form, coinciding with a time of great technological evolution and with the rise of the USA to superpower status" (14). Science fiction, in other words, has become an American genre with a global audience.

Accordingly, the themes, settings, and motifs of science fiction films are defined by specific American cultural circumstances. Therefore, an undergraduate course in an American Studies context can provide a historical overview of American science fiction films on the one hand, and enable engaged readings of each individual film not only as a reflection of important political, cultural, and social issues of their times but also as "an active force in its own right which is involved in the actual generation of ways of thinking and of attitudes" (Nünning 360) on the other. This is important because, as Carola Surkamp writes, "the choice of topics and formal properties not only reflects, but also influences the cultural issues of a given period" ("A Cultural Approach" 18). As a consequence, she further explains, "the analysis of the means of representation employed in a film can give insight into the cultural knowledge, the conceptions of reality and the ways of thinking of the society in which it was produced" (18). Surkamp's assumptions are based on the complex relationship between fictional texts and their contexts which she describes as follows:

Within culture-oriented and context-sensitive literary studies, literary texts and films are not seen as closed systems and static products, but they are rather conceptualized as being closely related to reality. ... However, this does not mean that films simply reflect reality. It is rather the case that they stand in a close dynamic interrelation with the reality outside the film, 
which is critically questioned by their choice of topics as well as formal means. On the one hand, films select a few of the diverse events and experiences of a multi-layered reality and present them with the aesthetic means of the audiovisual medium. ... On the other hand, films also influence the discussion on specific cultural themes in various discourses outside the medium: they gain productive character through the fictional interpretation of culture-specific experiences. (17-18)

In accordance with Surkamp's claim that "films should also be analysed with regard to their function as a medium that creates cultural meaning" (18), an undergraduate course on science fiction film obviously allows to link film studies learning objectives and the cultural studies perspective prevalent in the academic field of American Studies in a fruitful way. ${ }^{6}$

With this idea in mind, it makes sense to follow a chronological order when choosing the films that are to be watched and/or discussed in class, e.g. one representative film for each decade starting from the 1950s and ending with the 2000s. If the overall course objective, then, is to map and analyze American culture from the 1950s to the present through science fiction films, the selection of one film for each decade must be influenced by two considerations: (1) The films must be key works of the science fiction genre. (2) At the same time, the films have to reflect specific American cultural discourses of their periods. In other words, the six films to be selected as representative of the six decades covered in the course should lend themselves to analyses from a science fiction genre perspective as well as from a cultural studies perspective. As such, they can offer further understanding of the particular historical and political contexts of their respective periods.

The twentieth century saw a variety of American science fiction film productions. Despite this diversity, one can find recurring topics and themes: the increasing development of new technologies, a shift from an industrial economy to a globalized mass consumer and information society, growing influences of computer technology on humans and their everyday lives, and the encounter with the "other," the new, or the "alien" potentially made possible by technological inventions and advances in the fields of biotechnology and genetic engineering. Although these topics have been of varying relevance in public debates throughout the last six decades, and their prevalence in science fiction films as well as the images and rhetoric used to portray them have changed, they can be regarded as the underlying themes in many science fiction films of that time period. For the course "Of Body Snatchers and Cyberpunks: American Science Fiction Film from the 1950s to the Present," the syllabus listed the following six films: Don Siegel's Invasion of the Body Snatchers (1956), Stanley Kubrick's 2001: A Space Odyssey (1968),

6 On cultural approaches in American Studies and the foreign language classroom see also Delanoy and Volkmann, as well as Bach and Donnerstag. On media use in this context see Donnerstag and Volkmann. 
Richard Fleischer's Soylent Green (1973), Ridley Scott's Blade Runner (1982), the Wachowski brothers' The Matrix (1999), and Steven Spielberg's Minority Report (2002). In the next part of this section, we give a brief overview of each decade from the 1950s to the present in terms of their cultural climate, we present the central science fiction films of each period, and explain why we chose the six films above for the course.

The 1950s marked the beginning of the Cold War. After the end of World War II, communism was the new enemy and developments in science and technology fueled fears of potential nuclear contamination. Within science fiction, the 1950s are also the starting point for American science fiction film as a genre, as Vivian Sobchack writes ("American Science Fiction Film" 263). Productions such as Irving Pichel's Destination Moon (1950), which was based on a novel by Robert A. Heinlein, Byron Haskin's The War of the Worlds (1953), and George Pal's The Time Macbine (1960), both of which were adapted from novels by H.G. Wells, established the genre (Booker 4-7). Don Siegel's Invasion of the Body Snatchers (1956) - a classic alien invasion film - seems most appropriate for a case study of this decade because it can be analyzed both as an allegory about the fear of communist infiltration in the wake of McCarthyism and as commentary on domestic issues such as changing gender roles in post-war American middle-class society.

The 1960s were influenced by two important events: the space program as a product of Cold War competition between the United States and the Soviet Union and the Civil Rights movement in the United States. Both Sobchack and Marvin Keith Booker observe a decline in science fiction film productions during this period. 'The decade's emphasis on 'relevance,' and the clear importance of such phenomena as the anti-war movement, the Civil Rights movement, and the women's movement, made SF film seem frivolous to many," Booker explains the recession of the American science fiction film in the 1960s (12). Yet the genre also began to "strive for artistic seriousness" (12). Franklin Schaffner's Planet of the Apes (1968) and Stanley Kubrick's Dr. Strangelove: or How I Learned to Stop Worrying and Love the Bomb (1964) are among the science fiction films that reflected the cultural discourses of the period (Roberts, The History of Science Fiction 267; Sobchack, “American Science Fiction Film" 266). We decided to screen Stanley Kubrick's 2001: A Space Odyssey (1968) because it engages in public discourses about the U.S. space program and the counterculture movement in an original way. Featuring an artificial intelligence and an advanced alien race, it contemplates human evolution and can be read as a film that both celebrates and questions the technological progress. In terms of film analysis, 2001 is also a hallmark of special effects.

A growing social and political skepticism in the aftermath of the Civil Rights and other liberation movements fostered by the Watergate scandal (1972-4) and the end of the Vietnam War (1975) characterized American social, political, and cultural debates of the 1970s. Booker writes that because of its escapist potential, science fiction films experienced hitherto unknown popularity during that decade (14). Films like Steven Spielberg's Close Encounters of the Third Kind and George 
Lucas' Star W ars (both released in 1977) refashioned the adventure story "in which good triumphed over evil," thereby meeting conservative viewer demands (13-4). In contrast to Booker, Sobchack sees the science fiction film of the 1970s not as escapist but as "[m]ore adult, socially relevant, and mainstream than it had been previously, ... dealing with overpopulation, food shortages, urban blight, and aging" ("American Science Fiction Film" 267). Richard Fleischer's maybe lesserknown Soylent Green from 1973 lends itself to analysis because it is one of the science fiction films of the decade that depicts a dystopian view of American urban future. At the same time, the film reflects on environmental concerns, discourses on globalization, and the class and gender struggles of the decade.

The 1980s were marked by economic deregulation and political conservatism combined in the term Reaganomics. Other current debates revolved around multiculturalism and advances in computer technology. Films like Spielberg's E.T. the Extra-Terrestrial (1982) still used the escapist component popular during the 1970s in order to address mainly young viewers (Booker 14). The 1980s were also the years of the first Star Trek feature film sequels, whose eleven films span the 1990s as well as the first decade of the new millennium. Like the Star Wars franchise, Star Trek became one of the largest science fiction commercial enterprises in the United States and abroad. Rejecting the boundaries of high and low culture as well as rigid genre distinctions, postmodernism emerged as the predominating critical theory of the time, and it exerted a substantial influence on the science fiction film as well. Films such as Ridley Scott's Alien (1979) and Blade Runner (1982) extensively employ postmodernist aesthetics and themes, and academic critics such as Fredric Jameson received them as the "paradigmatic cultural expression of postmodernism" (Booker 15), as films that "symbolically mark a transition" in the depiction of the other, the alien, in the science fiction genre (Jameson 140). Other examples of the postmodern influence on science fiction film are James Cameron's The Terminator (1984) and Paul Verhoeven's RoboCop (1987), which both feature cyborgs: beings that are partly human and partly machine. The noir-science fiction film Blade Runner, which is based on Philip K. Dick's novel Do Androids Dream of Electric Sheep? (1968), became part of the syllabus because it is generally regarded a key icon of the postmodern period in science fiction filmmaking and is - with its dark, rainy and overpopulated cityscape - one of the most visually influential science fiction films. Contemplating what Booker terms "the distinction between humans and the products of their technology" (15) in the form of cyborgs, the film addresses many aspects of the contemporary condition of Western societies, such as fragmentation and questions of identity, alienation of the middle and working classes in the process of globalization, and the fear that machines will eventually fully replace human workers. Moreover, Blade Runner takes a critical perspective on the system of global capitalism and postmodern culture.

The 1990s were characterized by the end of the Cold War and by the beginning of the so-called new world order of political unipolarity as well as by the 
increasing significance of computer technology and the Internet in all walks of life. Roland Emmerich's Independence Day (1996) promotes a political discourse of a new world order in which America saves the world from aliens, who in the film are the worlds' new enemies (Booker 17). Furthermore, virtual reality was no longer a space confined to science fiction in films such as Robert Longo's Jobnny Mnemonic (1995) and Alex Proyas' Dark City (1998), but had also found its way into the 1990s everyday culture. On the one hand, Andy and Larry Wachowski's The Matrix (1999) - which served as our case study for the 1990s - comments on virtual reality and the "reliability of perception" (Rabkin, "American Science Fiction Film: No Final Frontiers"). On the other hand, its entire production depended on recent advances in computer technology. By applying Jean Baudrillard's theory Simulacra and Simulation - which the French philosopher describes as "the generation by models of a real without origin or reality: a hyperreal" (1) - The Matrix and its sequels The Matrix Reloaded and The Matrix Revolutions (both 2003) partake in popular and critical discourses on the information technologies of the decade.

The first years of the new millennium were marked by the terrorist attacks on September 11, 2001, and George W. Bush's subsequent "war on terrorism.” Increasing calls for state action that relied on new surveillance methods are taken up in Steven Spielberg's Minority Report (2002). We selected this film, which is based on a short story of the same title by Philip K. Dick, for the 2000s because it portrays a future scenario where everyday technologies such as instant messaging, closed circuit television, and satellite communication are used and abused in the name of global commerce and crime prevention. On a philosophical level, the film asks questions about the "reliability of knowledge," as Rabkin has pointed out ("American Science Fiction Film: No Final Frontiers"). In terms of successful film productions, the first decade of the twenty-first century witnessed the triumph of fantasy films over science fiction remakes, of which Spielberg's War of the Worlds (2005) and Francis Lawrence's I am Legend (2007) - an adaptation of Richard Matheson's 1954 novel and a remake of Ubaldo Ragona's The Last Man on Earth (1964) and Boris Sagal's The Omega Man (1971) - are probably the most well known examples. This increasing turn to earlier films can be read as a sign of a recent nostalgia of the science fiction genre (Booker 23-5). In terms of box office success, the epic fantasy screen adaptations of J.R.R. Tolkien's The Lord of the Rings by Peter Jackson (2001-3) and of C.S. Lewis' The Chronicles of Narnia by Andrew Adamson (2005) as well as the Harry Potter film adaptations have met the demands of contemporary viewers who are turning away from depictions of technologysaturated societies to worlds far away and purely imaginary.

This brief overview of American science fiction films since the 1950s has sought to show that the six films selected for the course "Of Body Snatchers and Cyberpunks" are among the cornerstones of the genre. They can be watched and analyzed as exemplary cultural products of their respective decades because they engage in popular discourses through their depictions of current events and de- 
velopments. In other words, the specific topics these films discuss and their distinct cinematic realizations "give insight into the cultural knowledge, the conceptions of reality and the ways of thinking of the society in which [they were] produced" (Surkamp, "Cultural Approach" 18). However, they present only one way of studying science fiction film and approaching American culture since the 1950s. Other films could be selected for this purpose just as well, possibly providing similar or new insights. What all six films on the syllabus share is that the various issues discussed in the works as well as their roles within American science fiction film may become fully apparent to the young non-American viewers once they analyze the means of representation and research the historical backgrounds of the periods in relation to the development of the genre.

\section{III}

The American Studies division at the University of Göttingen has a strong record in offering joint courses with other German universities or departments that are usually conducted in parallel sessions with identical or similar syllabi. At the end of the term, the students meet for a common symposium where they have the opportunity to deliver the papers they have worked on during the term and to discuss their research with peers and international scholars invited for the occasion. ${ }^{7}$ These joint courses have been offered as Hauptseminare, i.e. they were geared toward advanced students of American Studies and English Philology. In most cases, the student papers delivered at the common symposia were astonishingly full-fledged academic contributions. The discussions revealed that the students had acquired an in-depth knowledge of the topic, which prompted them to formulate challenging questions and interesting comments. Apparently, the course format - and the symposium in particular - not only helped to create or increase

Over the last decade, Frank Kelleter - chair of American Studies at the University of Göttingen - has offered and organized the following joint courses and corresponding symposia: "Sexuality and Seduction in Early America" (summer term 2004) with Ruth Mayer from the University of Hanover; "Hybrid Literatures, Hybrid Cultures" (summer term 2005) with Manfred Engelbert, and Annette Paatz from the Department of Romance Languages and Literatures at the University of Göttingen; "Authors: Theories of Literary Authorship (and American Case Studies)" (winter term 2005/2006) with Ruth Mayer from the University of Hanover; "Slavery and the Southern Plantation Romance" (summer term 2006) with Ulrich Mücke from the Department of Romance Languages and Literatures at the University of Göttingen; “The McSweeney's School of Fiction" (summer term 2008) with Laura Bieger from the John F. Kennedy Institute for North American Studies in Berlin.

Furthermore, Barbara Buchenau from the American Studies Program and Carola Hecke from the Teaching Methodology Program at the University of Göttingen have organized the following joint student conference "¿Postethnicity? - Identity Politics Reconsidered: North American Theories and Literary Practices in and outside of German Multicultural Classrooms" (summer term 2007). They have published an article on their teaching concept in the German-language journal Literatur in Wissenschaft und Unterricht, see Buchenau and Hecke. 
the learners' motivation but also affected the quality of the students' academic performance. This was not only true for the more advanced students of the Hauptstudium but also for students in their first and second years. In the summer term of 2008, students of two Proseminare offered by the English Department of the University of Göttingen met for an undergraduate conference on the Gothic novel, ${ }^{8}$ and here, too, the students presented excellent papers, as the more advanced students had done before them. In sum, parallel courses in combination with joint conferences obviously inspire students to overachieve academically both at the beginner and advanced levels.

Plans to teach parallel undergraduate courses on American science fiction film at two different universities - the University of Siegen and the University of Göttingen - that were to culminate in a joint undergraduate conference at the end of the term needed to draw on the experience of colleagues who had organized earlier events when deciding on the format, organization, and content as well as on the didactic approaches and methodology of the entire undertaking. The advantages of this teaching format are manifold: First, the participation of students and teachers from two different university contexts creates multiperspectivity. Upon meeting and exchanging their ideas at a joint conference, students are required to transfer, negotiate, and possibly revise their preconceived notions and thus engage in an active learning process. Second, in the context of the parallel courses and the joint conference, responsibility, personal initiative, and self-organization on the part of the students lead to better learning results and a heightened awareness of and confidence in their own academic achievements. This is closely related to a third point: The high motivational potential of the format signals to the students that their work is meaningful outside the classroom. Not only are students from two different universities interested in each others' work. If international experts are invited to the joint conference, and if this conference is open to the public, the students' academic performance gains even more importance. Finally, the learning atmosphere in class improves with the prospect of a joint conference where results can be presented to fellow students and a critical audience. ${ }^{9}$

While at some German universities the format of joint courses in connection with symposia or undergraduate conferences might be established and therefore familiar to advanced students, it may yet be unknown to those who are in their first and second years. It is therefore necessary to introduce the format to the students and to emphasize the degree of commitment required by this timeconsuming endeavor. The appeal of the undergraduate conference can be enhanced by inviting an international expert who gives a keynote at the conference,

8 Stephanie Sommerfeld and Dorothea Schuller organized "Discourse, Dreams, Delusion: The Enlightenment and the Gothic in Transatlantic Perspective" (July 4-5, 2008) as a joint undergraduate conference for their individual courses.

9 For advantages of the teaching format that combines parallel courses and joint conferences, see Buchenau and Hecke. 
attends the entire event, and participates in the discussion of the student papers. ${ }^{10}$ The students' work and achievements during the term are thus appreciated by an audience consisting of an expert and fellow students who engage with a diversity of student papers. This is not only highly motivating for students but also helps to accomplish a number of important learning objectives both inherent in the format and specific for the topic of American science fiction film, namely:

- Critical media literacy/film literacy: As mentioned above, media awareness is essential in today's media-saturated society. Based on a historical survey of American science fiction films from the 1950s to the present, critical media literacy means knowledge about, and engagement with, different filmic devices and their effects and insights into the historical, political, and cultural contexts in which the individual films were produced and released.

- Intercultural competence: The insights students gain into the historical, political, and cultural contexts of the science fiction films surpass, in fact, the learning objective of critical media and film literacy. They also further the students' intercultural competences, or more precisely: their knowledge about a specific historical, political, and/or cultural context, about the beliefs, mindsets and world views of another culture. As students receive and process this knowledge against the background of their own experiences and preconceived notions, it is important to actively discuss and reflect on exactly this reception process. This can be achieved with student papers, in class discussions, and of course at the conference, where students not only negotiate their findings with their fellow students from another university but (if possible) also with an expert from the target culture (in our case with a professor from an American university).

- Revising strategies: A course format in which students present their findings in the context of an undergraduate conference at the end of the term requires very specific preparations. Ideally, students should get the chance to present a draft version of their papers or their work in progress in class and thus have the opportunity to revise and improve their work according to the students' and the teacher's feedback. However, this would only be the starting point of the revising process because the students should continue to improve their papers after the conference, i.e. before handing in the term

10 It is recommendable to include (at least) one text written by the external expert into the course readings. Furthermore, biographical information about the expert's research and/or teaching will raise the students' interest in the conference and in meeting the expert.

We had the extraordinary opportunity to invite Prof. Eric S. Rabkin from the University of Michigan in Ann Arbor (USA) for the undergraduate conference "Of Body Snatchers and Cyberpunks: American Science Fiction Films from the 1950s to the Present" (Göttingen, July 3-5, 2009). As an expert in the field of science fiction studies, he not only enriched the conference with his brilliant keynote lecture "American Science Fiction Film: No Final Frontiers," he also contributed to the success of the event by interacting with the students, commenting on their papers, and sharing his great wealth of knowledge. 
papers. The academic performance at the conference itself, the presence of fellow students from the partner university, and the participation of an external expert are important motivational factors: Students are encouraged to apply revising strategies and consciously improve their work.

- Presentation skills: Developing and practicing presentation skills by giving an academic talk before an audience is important for all students, whether they will be future teachers or pursue other professional careers. These presentation skills include the command of the English language, i.e. the mastery of an adequate register and vocabulary for an academic presentation, confidence in public speaking, and the appropriate use of handouts and/or (audio)visual support (e.g. PowerPoint).

- Media competence: In contrast to the teaching goal of critical media literacy, media competence refers to the students' know-how concerning the use of PowerPoint or other presentation programs, clips and/or screenshots in their talks (and written papers). Film analysis depends on the serious engagement with the audiovisual material. Clips and/or screenshots serve as (audio)visual support for the students' arguments. Hence, students must not only learn how to recognize, analyze and interpret filmic devices in specific scenes or sequences, but also how to capture them as clips or screen shots and how to integrate them into a presentation.

- Organizational skills: Students should be involved in the preparation of the joint conference. They can be asked, for example, to put together their individual panels; students who act as panel chairs can prepare short presentations of the speakers and decide on how to proceed (if each presentation is followed by a discussion or if all presentations will be discussed at the end of the panel). Students can further be in charge of providing a place to stay for their fellow students from the partner university. This responsibility and personal initiative does not only practice organizational skills but also demands interinstitutional communication.

These teaching goals should further be reflected in the organization of the parallel courses. Joint conferences have proven to be most successful if both courses follow the same syllabus and students work with the same primary material and secondary literature. Especially discussions may turn out to be more difficult if the students follow different syllabi in their individual courses. While a common frame of reference might enable most advanced students to critically engage with other student papers and the talks delivered by experts, younger students probably still lack the skill to reflect on new insights within the short time of the discussion sections or to apply the knowledge they have gained throughout the term to new texts and contexts.

When teaching film and preparing the students for an undergraduate conference at the end of the term, two major questions will arise with regard to the practical organization of the course: (1) should the films be viewed in class or at 
home? (2) Should the students present their papers in a simulated conference situation or give a report on their work in progress? The answers to both questions depend on the number of students and sessions or on the available time slots and the possibility to schedule additional (screening) sessions. All solutions have their advantages and disadvantages. On the one hand, viewing the films on the syllabus in class is very time-consuming and might even require scheduling extra screening sessions. Moreover, some students will prefer to watch the films at home, with friends etc. A collective viewing experience, on the other hand, ensures active (as opposed to passive) watching and contributes to a productive atmosphere in class. Additional screening sessions may test but also strengthen the students' commitment and foster a common bond among the participants. Inclass viewings also avoid the practical and legal problem of providing each student with the DVDs and take into account that not all students may be able to watch the films at home.

Presenting papers in a mock conference situation as opposed to a report on the work in progress is likewise debatable. While the first option enables students to practice both the academic talk and the subsequent discussion in the (relatively) safe environment of the classroom, it can also be highly repetitive - as revised versions of the same talks will be given at the conference - and exhausting if too many students attend the class. Even if the presentations are no longer than ten minutes, the students will leave less time for practicing film analysis and for discussing more general aspects of the films in class. The second option, on the other hand, leaves more room for discussion and more time for the students' individual work on their presentations. However, revising strategies can only partly be applied if work in progress is presented.

Once the organization of the courses is decided upon, the content, didactic approaches and methodology gain center stage. The following questions are crucial: How can American science fiction film be taught? And more generally: How can film be taught in an American Studies context? Background readings on science fiction and science fiction film are, of course, indispensable, and teachers should provide excerpts from classic and more recent publications on the genre in literature and film. ${ }^{11}$ Yet, above all, a course on science fiction film - as any other course on film - must start with an introduction to film analysis. Students must be able to register cinematic means of expression and to make use of the exact terminology for different filmic devices if they are to analyze film scenes and sequences. For a historical, political, and cultural contextualization, they must further know how to semanticize these cinematic means of representation, and how to analyze their functions and effects on contemporary audiences as well as on viewers today.

11 On science fiction, see Gunn, Rabkin and Scholes, Suvin, Parrinder, Seed, James and Mendlesohn as well as Roberts. On science fiction film, see the recent studies by Sobchack, Hendershot, Telotte, Booker, and Cornea, or the essay collection edited by Sanders. 
Bernard F. Dick's Anatomy of Film and Timothy J. Corrigan's very accessible $A$ Short Guide to Writing about Film can be helpful tools for developing a vocabulary of technical terms as well as for learning how to take notes and write about film.12 It is useful to provide the students with a worksheet that lists selected terms and - if possible - illustrative figures for the main categories in film analysis: narrative, composition, camera/image, montage/editing, and sound. Having prepared their readings on film analysis taken from Dick and Corrigan or other introductions, students can fill in the worksheet with the respective definitions (e.g. for different field sizes, camera angles, cuts, and transitions) and add their own annotations. It is highly recommended to compare the students' notes in class - in preliminary pair work followed by class discussion - and to provide audio-visual examples for a selected number of terms such as the shot-reverse-shot pattern, different camera movements, match cut, jump cut, and varying forms of transitions, to name just a few. Rüdiger Steinmetz explains and illustrates these basic terms in volumes one and two of his Filme sehen lernen series that is equipped with additional, easy-tohandle DVDs. The newly acquired technical vocabulary - to which the students can and should refer throughout the term - will enable them to make specific statements about the cinematic aspects of the films discussed in class. Furthermore, it makes interpretative statements transparent to other students and intersubjectively comprehensible.

Apart from learning the terminology for filmic devices mentioned above, students will need to familiarize themselves with methods of sequence analysis and ways to take notes when watching and analyzing a film. As Corrigan writes, "despite the difficulty in taking your eyes off the screen momentarily, it is important to take notes of some sort during a first and only viewing" (26). For a start, he suggests, "to limit yourself to noting, with as much detail as possible, what you consider the three or four most important scenes, shots, or sequences in a film" (26). In her article "Teaching Films," Carola Surkamp offers another approach to taking viewing notes by providing a table that follows the distinction between literary (setting, characters, events, themes, point of view), dramatic (location/props, actors, costumes, make-up), and cinematic (camera, color/lighting, montage/editing, sound/music) aspects (9). ${ }^{13}$ This method is very practical for group work in class: As individual groups focus on one of the aspects during the film viewing and then exchange their observations, both the processing of audiovisual information and note taking can be considerably relieved. Most complex are the examples of sequence analyses from Helmut Korte's Einfïbrung in die systema-

12 Other excellent introductions include Monaco, Hickethier, Korte, and Jahn.

13 See also Nünning and Surkamp (245-75). 
tische Filmanalyse in which he uses elaborate graphs to analyze sound, camera movements, cuts, and transitions. ${ }^{14}$

Students should be introduced to these different approaches, yet, for the purpose of teaching a class on American science fiction film in an American Studies context, a middle ground that combines these (and other) ideas might be most appropriate. More precisely, we suggest the following set of guiding questions that the students should keep in mind when watching the films on the syllabus and preparing the analysis of specific sequences:

- Narrative: What happens in the sequence on the level of plot? What is the function of the sequence within the larger plot? How is the story being told (e.g. linear, flashbacks, flash-forwards)? How do the various channels of information used in film (visual image, print, speech, sound) interact to produce meaning? Can you recognize a source of narration (e.g. voice-over, on or off-screen commentary)? What is the narrator's perspective? Is he reliable?

- Composition: How would you describe the setting (on location or in the studio, historical/contemporary/futuristic)? Do certain props take a symbolic function? How do sets and props comment on the narrative? Is the space cluttered or empty? Is it a landscape or an interior? Does the space express a certain atmosphere or comment on a character's state of mind? Which colors are used (black and white/color/sepia, warm/cold/strong/washedout colors)? Can you discern any symbolic or subjective uses of colors? How would you describe the lighting (high-key or low-key)? What is illuminated and what is in the shadow? Are there any special lighting effects (e.g. shadows, spotlights)? How does the lighting enhance the expressive potential of the film? How do the actors interact verbally and/or non-verbally? Are there special groupings of characters? What do appearance, gestures, facial expressions signify? Are costume and make-up realistic/contemporary/futuristic? What do costumes signify with regard to social and cultural coding (class, gender, status, age)?

- Camera/Image: What are the field sizes used in the sequence (extreme long shot/long shot/medium shot/close-up/extreme close-up etc.)? Is it a deep/soft/sharp focus? Who or what is in and out of focus? How would you describe the camera angle (high/low/straight-on/eye-level)? Does the camera pan/tilt/zoom? Is it a tracking shot/crane shot/hand-held shot? Does the camera always follow the action? What are the types of shots used in the sequence (establishing shot/point-of-view shot/shot-reverse shot)?

- Montage/Editing: What comes before and what comes after the sequence? Are there any transitions (fade/dissolve/wipe/iris)? Are there any match

14 See Chapter 3 "Systematische Filmanalyse" (24-55), in which Korte provides a detailed introduction to film analysis. Sub-chapter 3.3 (39-53) is particularly helpful because it presents different ways and tools to visualize cinematic structures. 
cuts or jump cuts? Are the transitions gradual or abrupt? How do the transitions enhance the expressive potential of the film? Can you determine the purpose of editing (cutting for continuity, i.e. invisible cutting/thematic or dialectical montage/cross-cutting)? How long are the individual shots? Is the sequence fast-paced/slow-paced? Are there major changes in rhythm due to the narrative?

- Sound: What kind of music can you hear? Does it come from an on- or offscreen source (intra-diegetic/extra-diegetic)? Is it part of the story? Does it comment on the action? Is it linked to a character? With what purpose is music employed in the film? How does it direct our attention within the image? How does it shape our interpretations of the image? How would you describe the dialog (artificial/futuristic/foreign language, slang/dialect)? Do different characters use different kinds of language? Are there silences? Are the sound effects used in the sequence artificial or natural? Do they have an on- or off-screen source? Does the sound belong to the action? Is there subjective sound? If there is a voice-over: Who is speaking? Is the voice-over narrator part of the action or outside of it? ${ }^{15}$

The set of guiding questions could be provided as a worksheet, and the students could form five expert groups, each group dealing with one cluster of guiding questions. While the expert groups remain the same throughout the course - again to enhance the bond among the participants and to create a productive work atmosphere - the respective guiding questions might rotate with each film. The focus on one specific filmic category (narrative, composition, camera/image, montage/editing, or sound) would not only ensure active viewing on the part of the students but would also constitute an important practice of film analysis in the while-viewing phase. This approach to science fiction films could be first put to use in an exemplary analysis of the opening sequence of Don Siegel's Invasion of the Body Snatchers (1956). Ideally, the students' observations should be discussed and commented on in class. However, if there is not enough time, it is also possible to do so on an Internet platform or blog, where students can post their notes and interact with each other. ${ }^{16}$

A forum for discussion on an Internet platform/blog and/or a designated time slot in class should also be reserved for pre- and post-viewing activities. Having read a designated selection of secondary literature on the historical background of the time in which the film was produced or on the film itself, students could for-

15 The set of guiding questions is based on Timothy J. Corrigan, Helmut Korte, and Carola Surkamp ("Teaching Films"). It is also indebted to Eric Rentschler and Anton Kaes and takes up ideas from Dick and Monaco.

16 In the two courses "Of Body Snatchers and Cyberpunks: American Science Fiction Films from the 1950s to the Present" taught at the University of Göttingen and the University of Siegen, the Internet-based learning sites Stud.IP (Göttingen) and Moodle (Siegen) were used as platforms for discussion throughout the term. 
mulate notes about their expectations before watching the film. It should be stressed that the students attempt to make statements from film analytical and cultural studies perspectives. This pre-viewing activity is important and usually very productive because, as Corrigan states, preliminary notes help students to make economical use of their time and to recognize key sequences, shots, or narrative facts, which subsequently enables them to come up with a thesis (29-30). Secondary literature on the cultural, historical, and political background helps students to situate the films in a larger U.S. American context. Formulating a thesis and presenting a paper in class and/or at an undergraduate conference will constitute the most challenging post-viewing activity for students in their first and second years. Teachers should therefore provide assistance and feedback during the process of finding an adequate topic and developing a tentative thesis.

In order to ensure active course participation during the presentations, students could focus on the following questions: What do you think about the presentation? Are there points with which you agree or disagree? Could you find additional pieces of evidence to support the thesis or would you rather take a different approach to the aspects pointed out? Answering these questions not only fosters critical engagement with the topics and theses presented in class. It also serves as a preparation for the discussion sections at the conference. Formulating critical comments and questions constitutes an important aspect of academic performance and has to be practiced accordingly. The safe environment of the classroom is an ideal place for "trial and error" experimentations before the undergraduate conference.

For all those students who feel that there is never enough time for discussion in class or that important issues have not been raised, the teacher can provide a space to post their ideas and final thoughts on the Internet platform or blog. Students should also be encouraged to formulate concluding remarks as a post-viewing activity and to reconsider the preliminary notes they have formulated before watching the film and if those issues were addressed in class.

Considering the parallel undergraduate courses on American science fiction in Göttingen and Siegen as a case study for the teaching approach presented here, it might be interesting to add that the format, organization, and content as well as the didactic approaches and methodology have received mostly positive feedback from the students both in final class discussions and on anonymous evaluation forms. The main points of critique were that the course was extremely timeconsuming - with (extra) screening sessions and a three-day conference - and that scheduling the undergraduate conference at the end of the term interfered with exam preparations. Yet, positive opinions prevailed: Most students enjoyed the productive atmosphere in class, liked the discussions, and thought that the conference with our external expert Prof. Eric S. Rabkin and the fellow students from Göttingen and Siegen were special and enriching experiences they would not want to miss. What is more important from the teachers' perspective is the students' 
efforts and achievements, or, in other words, the fact that all students excelled in their academic performance in class, at the conference and in their term papers.

\section{IV}

The present volume documents the hard work, dedication, and commitment of thirteen students from Göttingen and Siegen who have participated in the course "Of Body Snatchers and Cyberpunks: American Science Fiction Film from the 1950s to the Present" and the concluding undergraduate conference in the summer term of 2009. They have repeatedly revised and improved their contributions: first, after presenting their initial ideas in class; then, after the undergraduate conference; and, finally, after handing in their term papers. The results of this continuous revision are collected in this volume. The progress of the students during the entire process - from conceiving their ideas for the paper to the final publication - has been really astounding. This is also true for those students whose papers could not be included in this book. Unfortunately, the editors had to select the best among many excellent papers. The final result are twelve student essays one is co-authored by two students from Siegen - divided into four sections that group the essays according to shared research interest and do not reflect the chronological approach taken in the course. This arrangement brings to the fore lasting, changing, and recurring themes as well as stylistic and filmic devices that are part of both American culture and the science fiction genre.

Part I is entitled "The Look and Sound of Science Fiction Film." All three contributions in this section focus on the filmic use of visual effects, special effects, and sound that evokes what could be called a particular science fiction atmosphere. First, Jörn Piontek's essay analyzes different examples of visual subversion in Richard Fleischer's Soylent Green (1973). In Vivian Sobchack's words - on whose definition Piontek's analysis is based - visual subversion is a cinematic technique that is often used in science fiction films and that can be understood as "the alienation of the familiar" (Screening Space 107). Piontek shows how disturbingly familiar images are used to create the effect of a threateningly possible dystopian future. Dennis Edelmann then explores the special effects in the Wachowski Brothers' The Matrix (1999). He argues that critics have mostly focused on the revolutionary content and unique visuals of the film but have neglected the groundbreaking special effects and their impact on the film industry. Edelmann's discussion of the special effects in The Matrix pays particular attention to how reality is deconstructed and how bullet time is employed in the film. In the next essay, Fabian Grumbrecht turns to Stanley Kubrick's 2001: A Space Odyssey (1968). He provides a close reading of the sequence in which astronaut Dave Bowman turns off the board computer HAL 9000. According to Grumbrecht, this specific sequence stands in stark contrast to other cinematic showdowns in which the 
antagonist is destroyed - not only on the level of plot but also on the visual and aural levels.

Part II, entitled "Social and Political Commentaries," contains four essays that deal with the critical potential of science fiction films. They investigate to what extent science fiction films can participate in the cultural, political, and religious discourses of their respective decades. First, Niklas Franzen takes a close look at "Jupiter and Beyond the Infinite" - the Stargate sequence in 2001 - and examines its popularity with young adults of the 1960s U.S. counterculture. While contemporary critics were convinced that young viewers enjoyed the innovative, highly psychedelic sequence in 2001 because of its hallucinogenic effects (commonly enhanced by the use of drugs), Franzen reads the success of the sequence also as an expression of opposition by relating the film's release to the Vietnam War, the Civil Rights Movement, and student protests in the 1960s. In the following essay, Manfred Alexander Müller analyzes manhood and masculinity in Don Siegel's Invasion of the Body Snatchers (1956). He interprets key scenes of the movie as highly charged reflections on the post-war decline of small-town patriarchy and the related threat to male social and political dominance in the United States. Philipp Stückrath's reading of Steven Spielberg's Minority Report (2002) then links the theme of personal liberty vs. state control prevalent in the post-9/11 film to the current political situation in the United States. Even though the film is based on a science fiction short story by Philip K. Dick that was first published in 1956, Stückrath reveals many similarities between the celebrated yet dysfunctional PreCrime system in the film and the institutions and laws of state control in the present-day United States that were established after the terrorist attacks in 2001 (such as the Department of Homeland Security and the USA PATRIOT Act). Part II closes with Moritz Emmelmann's analysis of religion in Soylent Green. Emmelmann argues that in the context of the extreme social, economic, and moral crisis depicted in Soylent Green the Christian Church is presented as a charitable institution and stronghold of spiritual leadership and moral integrity.

Part III of this collection is entitled "Themes and Motifs of Science Fiction Films." The section starts with an essay by Dennis Kogel and Iris Schäfer. They look at a key motif of science fiction film and literature: the doppelgänger. Kogel and Schäfer provide a survey of five distinct motifs used in science fiction film and TV series (clones, artificial intelligence, time travel, parallel universes, virtual identities) in order to demonstrate how the idea of the self is challenged in contemporary science fiction productions, and how it relates to modern capitalism in an information society. In the second essay of this section, Stefanie Schwarz analyzes the importance of vision and the eye motif - another recurring motif in science fiction films - in Minority Report. Schwarz reads images of eyes that serve to identify citizens in the dystopian Pre-Crime society of the film as well as visions of future crimes arranged and interpreted by the Pre-Cops in the context of power relations, determination, and reliability. Solveig Burfeind's reading of Invasion of the Body Snatchers finally focuses on elements of film noir in the 1950s film and exam- 
ines whether Becky Driscoll can be classified as a femme fatale. Burfeind shows that Becky shares many characteristics with a femme fatale: Not only does Becky look like a femme fatale (especially when compared to other female characters in Invasion), as a divorced woman she is also sexually experienced and effectively seduces Miles Bennell, whom she later tries to turn over to the alien pod people.

The final section of this volume, Part IV, is entitled "(De)Constructing Bodies and Identities" and consists of two essays that deal with the body and its various functions and realizations in science fiction film. First, Benjamin Ryan Ulonska reads Invasion of the Body Snatchers and its remakes as a narrative that combines elements of science fiction and horror in order to comment on changing perceptions of the body in the respective decades of the film's remakes. Ulonska argues that the specific horror elements and outer appearance of the aliens - their bodies - in these invasion films reflect the dominant political, cultural, and social anxieties of the decades in which the individual versions were produced. In the last student essay, Gina Ziebell analyzes the realization of the cinematic body in times of information technology in The Matrix. Ziebell examines the human body and identity in terms of the obsolescence of the body and the construction of the virtual subject by relating it to the question of agency based on space, mobility, and bodily control inside and outside the Matrix.

The volume closes with an essay by Eric S. Rabkin in which he describes his personal experiences and lifelong fascination with science fiction films. Rabkin's autobiographical essay is entitled "The Creature from Brooklyn: My Life and Science Fiction Film" and tells the story of a young boy from Brooklyn who discovers and falls in love with science fiction and eventually becomes an acclaimed teacher and internationally recognized critic of the field. It is his courtesy of contributing this original essay to the present volume as well as his invaluable presence at the conference, his instructional comments during the publication process, and his enthusiastic dedication to the entire project for which the editors are most grateful. 


\section{Works Cited}

Aldiss, Brian. Trillion Year Spree: The History of Science Fiction. 1973. London: Gollancz, 1986. Print.

American Studies as Media Studies: 53. Jahrestagung der Deutschen Gesellschaft für Amerikastudien. English Department / American Studies, U of Göttingen, n.d. Web. 16 Dec. 2010. <http://www.amstud.uni-goettingen.de/files/Progheft_AmStud_end.pdf>.

Bach, Gerhard, and Jürgen Donnerstag, eds. Teaching American Studies in the Twenty-First Century. Spec. issue of Amerikastudien/American Studies 52.3 (2007). 315-60. Print.

Bachmann-Medick, Doris. Cultural Turns: Neuorientierungen in den Kulturwissenschaften. Reinbek bei Hamburg: Rowohlt, 2006. Print.

Baudrillard, Jean. Simulacra and Simulation. Trans. Sheila Faria Glaser. 1994. Ann Arbor: U of Michigan P, 2007. Print.

Booker, Marvin Keith. Alternate Americas: Science Fiction Film and American Culture. Westport, CO: Praeger, 2006. Print.

Buchenau, Barbara, and Carola Hecke. "Die Literatur zur eigenen Sache machen: Offener, fächerverbindender Unterricht in der universitären Fremdsprachenlehrerausbildung." Literatur in Wissenschaft und Unterricht 41.2 (2008): 179-97. Print.

Cornea, Christine. Science Fiction Cinema: Between Fantasy and Reality. Edinburgh: Edinburgh UP, 2007. Print.

Corrigan, Timothy J. A Short Guide to Writing about Film. 6 ${ }^{\text {th }}$ ed. New York: PearsonLongman, 2007. Print.

Dick, Bernard F. Anatomy of Film. New York: St. Martin's P, 1978. Print.

Delanoy, Werner, and Laurenz Volkmann, eds. Cultural Studies in the EFL Classroom. Heidelberg: Winter, 2006. Print.

Donnerstag, Jürgen and Laurenz Volkmann. "Introduction: Media and American Studies in the EFL-Classroom." Media and American Studies in the EFL-Classroom. Ed. Jürgen Donnerstag and Laurenz Volkmann. Heidelberg: Winter, 2008. 5-14. Print.

---, eds. Media and American Studies in the EFL-Classroom. Heidelberg: Winter, 2008. Print.

Freese, Peter. "American Studies and EFL-Teaching in Germany: A Troubled Relationship." Amerikastudien/American Studies 50.1/2 (2005): 183-229. Print.

Gunn, James. Alternate Worlds: The Illustrates History of Science Fiction. Englewood Cliffs, NJ: Prentice-Hall, 1975. Print.

Hendershot, Cyndy. Paranoia, the Bomb, and 1950s Science Fiction Films. Bowling Green, OH: Bowling Green State U Popular P, 1999. Print.

Hickethier, Knut. Film- und Fernsehanalyse. $2^{\text {nd }}$ ed. Stuttgart: Metzler, 1996. Print. 
Jahn, Manfred. "A Guide to Narratological Film Analysis." Poems, Plays, and Prose: A Guide to the Theory of Literay Genres. English Department, U of Cologne, 2003. Web. 10 Mar. 2009. <http://www.uni-koeln.de/ ame02/pppf.htm\#F5>.

James, Edward. Science Fiction in the $20^{\text {th }}$ Century. Oxford: Oxford UP, 1994. Print.

Jameson, Fredric. Archaeologies of the Future: The Desire Called Utopia and Other Science Fictions. New York: Verso, 2005.

--- and Farah Mendlesohn. The Cambridge Companion to Science Fiction. Cambridge: Cambridge UP, 2003. Print.

Kelleter, Frank and Daniel Stein, eds. American Studies as Media Studies. Heidelberg: Winter, 2008. Print.

---. "American Studies as Media Studies." American Studies as Media Studies. Ed. Frank Kelleter and Daniel Stein. Heidelberg: Winter, 2008. ix-xvi. Print.

Kellner, Douglas. Media Culture: Cultural Studies, Identity and Politics between the Modern and the Postmodern. New York: Routledge, 1995. Print.

Korte, Helmut. Einführung in die Systematische Filmanalyse. 2nd. ed. Berlin: Erich Schmitt Verl., 2001. Print.

Monaco, James. How to Read a Film. New York: Oxford UP, 1977. Print.

Maxwell, Richard. "The Historiography of Fiction in the Romantic Period." The Cambridge Companion to Fiction in the Romantic Period. Eds. Richard Maxwell and Katie Trumpener. Cambridge, Cambridge UP, 2008. 7-21. Print.

Nünning, Ansgar. "Towards a Cultural and Historical Narratology: A Survey of Diachronic Approaches, Concepts, and Research Projects." Anglistentag 1999 Main Proceedings. Ed. Berhard Reitz and Sigrid Rieuwerts. Trier: WVT, 2000. 345-73. Print.

---, and Carola Surkamp. Englische Literatur unterrictten: Grundlagen und Methoden. SeelzeVelber: Klett/Kallmeyer, 2006. Print.

Parrinder, Patrick, ed. Learning from Other Worlds: Estrangement, Cognition and the Politics of Science Fiction and Utopia. Liverpool: Liverpool UP, 2000. Print.

---. Science Fiction: A Critical Guide. London/New York: Longman, 1979. Print.

Rabkin, Eric S. "American Science Fiction Film: No Final Frontiers." Of Body Snatchers and Cyberpunks: American Science Fiction Films from the 1950s to the Present. Undergraduate Student Conference. Georg-August-Universität Göttingen. 3 July 2009. Keynote speech.

---. "Science Fiction." International Encyclopedia of Communications." Eds. Eric Barnouw et al. New York: Oxford UP, 1989. 19-23. Print.

--- and Robert Scholes. Science Fiction: History, Science, Vision. New York: Oxford UP, 1977. Print.

Rentschler, Eric and Anton Kaes. Reading a Film Sequence. U of Victoria, n.d. Web. 19 Apr. 2009. <http://web.uvic.ca/geru/439/seq.html>. 
Roberts, Adam. Science Fiction. London: Routledge, 2000. Print.

---. The History of Science Fiction. Houndmills: Palgrave, 2006. Print.

Sanders, Steven M., ed. The Philosophy of Science Fiction Film. Lexington, KY: U of Kentucky P, 2008. Print.

Seed, David, ed. A Companion to Science Fiction. Malden, MA: Blackwell, 2005. Print.

---. American Science Fiction and the Cold War: Literature and Film. Edinburgh: Edinburgh UP, 1999. Print.

Seidl, Monika. "Visual Culture: Bilder lesen lernen, Medienkompetenz erwerben." Der fremdsprachliche Unterricht Englisch 87 (2007): 2-7. Print.

Sobchack, Vivian. "American Science Fiction Film: An Overview." A Companion to Science Fiction. Ed. David Seed. Malden, MA: Blackwell, 2005. 261-74. Print.

---. Screening Space: The American Science Fiction Film. New Brunswick, NJ/London: Rutgers UP, 1999. Print.

Surkamp, Carola. "A Cultural Approach to Films in the Foreign Language Classroom: Gender Roles and Questions of Identity in The Hours." Media and American Studies in the EFL-Classroom. Ed. Jürgen Donnerstag and Laurenz Volkmann. Heidelberg: Winter, 2008. 15-30. Print.

---. "Teaching Films: Von der Filmanalyse zu handlungs- und prozessorientierten Formen der filmischen Arbeit." Der fremdsprachliche Unterricht Englisch 68 (2004): 2-12. Print.

Suvin, Darko. The Metamorphosis of Science Fiction: On the Poetics and History of a Literary Genre. New Haven / London: Yale UP, 1979. Print.

---. Positions and Prepositions in Science Fiction. Basingstoke: Macmillan P, 1988. Print.

Steinmetz, Rüdiger. Grundlagen der Filmästhetik: Filme sehen lernen 1. 8th ed. Frankfurt/M.: Zweitausendeins, 2007. Print.

---. Licht, Farbe, Sound: Filme sehen lernen 2. Frankfurt/M.: Zweitausendeins: 2008. Print.

Telotte, Jay P. Science Fiction Film. New York: Cambridge UP, 2001. Print.

Voigts-Virchow, Eckart. Introduction to Media Studies. Stuttgart: Klett, 2005. Print. 